\title{
The Relationship between Speaking Anxiety and Oral Fluency of Special Education Arab Learners of English
}

\author{
Ashraf Atta M. S. Salem ${ }^{1} \&$ Mosaad Abu Al Dyiar ${ }^{1}$ \\ ${ }^{1}$ Center of Children Evaluation and Teaching, Kuwait \\ Correspondence: Ashraf Atta M. S. Salem, Part-time Researcher, Center of Children Evaluation and Teaching, \\ Kuwait. E-mail: sirashrafams@hotmail.com
}

\author{
Received: March 17, 2014 Accepted: April 30, 2014 Online Published: May 26, 2014 \\ doi:10.5539/ass.v10n12p170 URL: http://dx.doi.org/10.5539/ass.v10n12p170
}

\begin{abstract}
The current study aimed at investigating the relationship between speaking anxiety and oral fluency of Arab intermediate school students. It also investigates the differences between male and females students in speaking anxiety profile and their oral fluency performance. The sample of the study consists of (121) students in intermediate school in the state of Kuwait (68 males and 53 females). The mean age of the sample is (9.74) years and standard deviation is (1.46) years. The descriptive research design was used. The researcher used speaking anxiety scale that was developed by Berko et al. (2004) and an oral fluency skills interview. Results of the study showed that there are positive relation between student speaking anxiety and their performance in oral performance skills of male students and the total sample of the study. It is also found that no relations were found between female students speaking anxiety and their oral fluency performance. Findings indicated that there were statistically significant differences between male and female students in oral fluency in favor of male students. Whereas, no statistically significant differences were found between male and female students in their speaking anxiety.
\end{abstract}

Keywords: speaking anxiety, oral fluency, non-speakers of English

\section{Introduction}

Speaking is an important skill as it is considered the bridge that connects people talking the same language. It helps people express their thoughts, ideas, feelings and emotions to others. It is one of the productive skills-speaking and writing-that learners use to produce language whether in a spoken or a written form. Illiterate people do not find any other means to convey and transfer their ideas except through speaking as they are naturally unable to write. EI-Basel $(2008$, p. 74) argues that speaking skills have been found a fundamental skill necessary for a person's success in life. Speaking skills cover a wide range, from engaging in simple conversation to formal public speaking.

Speaking skills play a vital role in communication process. It is the most important type from the types of linguistic activities. Developing speaking skill helps in creating an effective connection among the individuals' society. It is an active part in their daily life and a tool of learning (Dorgham, 2011, p. 1).

On a related context, Alia (2007, p. 1) views that "speaking is a complicated mental process and a productive skill." Also, Brown (2001, p. 9) argues that speaking is not a single skill, rather speaking is an interactive process of constructing meaning that involves producing, receiving and processing information. In addition, Harmer (2001, p. 15) points out that speaking include two categories; accuracy and fluency. This means that developing speaking skill involves the correct use of vocabulary, grammar, pronunciation and having the ability to speak spontaneously.

Providing students with an effective environment enables language speakers to speak fluently and interact freely with each other. This encouraging environment makes learners speak fluently without anxiety and apprehension. Multiple Intelligences Theory enables learners to discuss positive strengths in all children and to plan appropriate learning strategies for a more effective classroom environment” (El Naggar, 2000, p. 25). Consequently, the targeted effective environment cannot be provided through the traditional strategies of instruction. The traditional teaching strategies treat students in a uniform way. It does not pay a due attention to the individual differences among language learners. This does not give equal opportunities for students to speak or listen. The 
students who are dominant in the speaking and listening practices are those who are linguistically-talented only.

Foreign Language learning is affected by a group of factors; among these factors are the affective factors. Speaking is affected by these affective variables; therefore, foreign language speaking anxiety is one of the most prominent factors that has a debilitating influence on the oral performance of students learning English whether as a second language or a foreign Language.

Foreign language anxiety is a construct that exists in all of the cultures where it has been studied. However, the literature provides a limited empirical evidence to indicate whether foreign language students and teachers are aware of it (Trang, Baldauf, \& Moni, 2013).

Foreign language anxiety stems from a fear of students' failure to achieve their goals. According to Horwitz et al., (1986, p. 127), there is "a type of performance anxiety stemming from a fear of failure". The fear of failing a test pervades every school environment and is the prevailing cause of writing apprehension is L2 writing situations.

Melouah (2013, p. 65) view that foreign language speaking anxiety is one of several factors that affect students oral production in foreign language that they are required to use. Thus, foreign language speaking anxiety stimulates various adverse learning phenomena such as students' reluctance to participate in the speaking activities. Eventually, foreign language speaking anxiety may lead to students' poor performance and academic achievement. According to Mohamed and Wahid (2009), foreign language speaking anxiety represents a pervasive detrimental factor which leads to low performance in both speaking skills and oral performance.

The work done by Horwitz et al. (1986) was a standing point as it focused on the detrimental impact of affective variable on foreign language teaching and learning. He argues that low proficiency in English language cannot be only induced to the cognitive factors, rather emotion and affect is an integral part of this problem. Therefore, oxford (1999) ranked foreign language anxiety to be one of the highest factors that influence foreign language learning.

Language anxiety is an affective state denoting that learners feel insecurity while learning. It has a negative impact on their learning. It makes teachers and instructors perplexed as students who suffer from anxiety are usually smart and achieve high academic achievement in other disciplines. Melouah (2013, p. 66) view that language anxiety can be defined as "a state of unease, a Kind of troubled feeling in the mind marked by excessive uneasiness". According to Idri (2012). Language anxiety is an effective state which is manifested in a feeling of insecurity as well as a diffused trouble. Anxiety disorders are prevalent in the general population (Kessler et al., 1994) and can have a damaging influence on people's lives.

Due to its ultimate importance in students' performance, foreign language speaking anxiety was extensively dealt with in various studies (Subasi, 2010; Liu, 2007; Tsiplakides \& Keramida, 2009; Fang-Peng \& Dong, 2010; Melouah, 2013). Anxiety has been found to negatively influence speaking performance (Aida, 1994).

Yahya (2013) investigated the factors which lead to speaking anxiety among speech communication course students' in the English classroom. The three domains that usually affect students' performance (test anxiety factors, communication anxiety factors, and fear of negative feedback anxiety have been investigated by means of a well-known scale (FLCAS) in addition to more items were added to the scale by the researcher. The sample of the study consisted of (104) students at the Arab American University in Palestine. Findings of the study revealed that the fear of negative feedback received the highest mean, followed by communication anxiety and test anxiety received the lowest mean.

On a related context, Lindy (2006) studied the second language speaking anxiety, the relationship between anxiety and second language performance, and the major reported causes of second language anxiety. The participants in this study were Two hundreds seventy five advanced English for academic purposes (EAP) students studying on intensive EAP courses immediately prior to entering Australian universities. The second language speaking anxiety scale (SLSAS) was developed for the study. This instrument provided evidence for a dual conceptualization of anxiety reflecting both oral communications within and outside the language learning classroom. Results of the study indicated that the most frequent source of anxiety was interacting with native speaker. Evidence for two types of anxious language learner emerged; retrieval interference and skills deficit.

One of the most prominent figures in investigating foreign language anxiety was Horwitz et al (1986). His work helped other researchers greatly to explore levels of language anxiety and the most effective approaches to alleviate anxiety. One of his prominent contributions was to design the foreign Language Classroom Anxiety Scale (FLCAS) in 1986 to make educators able to explore both the scope and severity of students' anxiety and its probable effects on learning contexts. In addition, Horwitz et al (1986) identified three sources of foreign language anxiety; communicative apprehension, fear of negative evaluation and test anxiety. Communicative 
apprehension refers to the students' inability to express their ideas, thoughts and feelings in a form of words. Fear of negative evaluation denotes an apprehension and even avoidance of situations including evaluating his oral production. Test anxiety refers to the apprehension in academic exam settings.

\subsection{Speaking Anxiety and Krashen's Affective Filter Hypothesis}

Krashen (1985) views that affective variables are one of the most important factors which may impede students from learning. Therefore, there is a so called "affective filter" or a mental block" that correlates negatively with learning. When this block or filter is high, learning will be low and vice versa. Thus, learning can happens with high levels when this affective filter is lowered to the utmost degree. But when teachers-in their classrooms-are not able to lower or even get rid of this affective filter or block, students learning will undoubtedly influenced or even impeded.

\subsection{Environment and Anxiety in Spoken Language Learning}

The influence of affective factors in the language classroom is apparent, this influence is induced through the risk of embarrassment or humiliation the student may face when he/she speaks in the target language (Kessler, 2010). Celce-Murcia, Brinton, \& Goodwin (1996) argues that speaking in a foreign language-unlike writing, which we are accustomed in evaluating, critiquing, and revising-may result in the most heightened form of affect that a student can experience. It is worth noting that the role of the environment becomes increasingly important triggered by the fact that speaking can heighten anxiety and anxiety negatively affects fluency.

To sum up, numerous studies addressed speaking anxiety in general, few studies dealt with speaking anxiety in relation to students' oral fluency whereas very few studies addressed this type of relationship in a sample of special education pupils who suffer learning difficulties. Therefore, the current study has attempted to fill this gap by investigating the relationship between speaking anxiety and oral performance of the primary stage special education pupils. Accordingly, this study tried to answer the following questions: Are there any statistically significant differences between males and females in both speaking anxiety and oral fluency skills? Also, it tried to provide answer to the question: Are there any statistically significant differences in the mean scores of the pupils' speaking anxiety and oral fluency skills? The third question the study tried to answer is that: Is the pupils' oral fluency performance a good predictor of their speaking anxiety in the educational settings? Answers to these questions can help teachers minimize the pupils' speaking anxiety and develop their speaking skills.

\section{Methods}

The current study adopts the descriptive research design. The descriptive research design depends on describing certain phenomenon and doing comparisons among students based on the study variables two variables are intended in the current study; English Language speaking anxiety and oral fluency skills.

\subsection{The Sample Power and Precision}

\subsubsection{The Psychometric Sample of the Study}

The psychometric sample of the study consists of (60) primary school pupils with learning difficulties (special education). Their mean age level is (1.82) years old. The authors used the psychometric sample so as to make sure of the psychometric efficacy of the study scale.

\subsubsection{The Basic Sample of the Study}

The basic sample of the study consists of (121) primary special education schools (students with learning difficulties). The authors used this sample to verify the correlation study hypothesis. The sample of the study consists of (53) male pupils and (68) female pupils with mean age (9.74) and standard deviation (1.46) years.

\subsection{A Semi-Structured Interview}

A semi-structured interview was developed and used by the researchers in order to assess the students' oral fluency skills. The interview starts with some shorts questions about themselves. The second part of the interview includes giving pupils the opportunity to select a topic to talk freely about the second part of the interview provides pupils the opportunity to speak fluently on a topic previously prepared.

\subsection{Measures of Study}

English Language speaking anxiety scale: the scale was developed by Berko, Wolvin \&Wolvin, (2004). The scale includes six items following Likert scale with five alternatives (5 means strongly agree, 4 refers to agree, 3 stands for I don't know, 2 means disagree and I refers to strong disagree).

The student score in the speaking anxiety scale ranges from (6) to (30) points. If the student's score is (18), then he is similar to the majority of Europeans and Americans in their speaking anxiety. 


\subsubsection{Reliability of the Study Tools}

\subsubsection{Reliability of Study Tools}

1) Reliability was calculated through three different methods:

Alpha Cronbach Method which depends on the correlation coefficient of items among each other in each scale as well as the correlation coefficient between each item and the total score of the test.

2) Test-Retest Method. The test was administered twice with 20 minutes time interval between the two test sessions order to eliminate the effect or memorizing. This is to measure the reliability coefficient which is called stability coefficient which is influenced by error caused by discrepancy in evaluation.

Table 1. Reliability coefficient of oral fluency and anxiety of speaking

\begin{tabular}{lllll}
\hline \multirow{2}{*}{ Tests } & Means $(\mathbf{n}=\mathbf{3 0})$ & & \multicolumn{2}{c}{$\begin{array}{l}\text { Females }(\mathbf{n}=\mathbf{3 0}) \\
\text { Test retest }\end{array}$} \\
\hline Oral fluency Test & Alpha & Test retest & Alpha & $\mathbf{0 . 8 7}$ \\
Anxiety of speaking Test & $\mathbf{0 . 8 4}$ & $\mathbf{0 . 9 4}$ & $\mathbf{0 . 8 6}$ & $\mathbf{0 . 8 0}$ \\
\hline
\end{tabular}

Close inspection of Table 1 reveals high reliability coefficients for both male and female participants in the battery of tests of Oral fluency and Anxiety of speaking.

\subsubsection{Validity of Study Tools}

Validity of the tools of the study was calculated using criterion-related validity. Correlation coefficient of pilot study sample (60 participants) in Diagnostic Reading fluency Test (Elbeheri, Abo Al-Diyar, Everatt, \& Mahfoudhi, 2010 ) and the Oral fluency Test was calculated (0.65). With regard to criterion-referenced validity of the Anxiety of speaking Test, the correlation coefficient was (0.47-0.62).

\subsection{Procedures of Administration}

The process of administering the tools of study went through many successive stages as follows:

1) The first stage: In this stage the sample of the study was selected intentionally from special education pupils (children with learning difficulties). At this stage the authors verified the psychometric conditions of the English Language speaking Anxiety scale.

2) The second stage: In this stage witnessed the process of implementing the diagnostic tools of the study. Those tools included the English Language speaking anxiety scale and the oral fluency test (interview).the implementation procedures took place in the second term (semester) of the academic scholastic year (2011-2012).

\subsection{Statistical Analysis}

After collecting and tabulating the study data, the researcher used SPSS to work out both the descriptive statistics and the inferential statistics.

\section{Results}

\subsection{The First Hypothesis}

There are statistically significant differences between male and female pupils in both speaking anxiety and oral fluency skills. The researchers used T-test in order to test the significance of mean differences of scores of males and females.

Table 2. Mean score, standard deviations and T-test values of males and females in tests of oral fluency and anxiety of speaking

\begin{tabular}{cccccc}
\hline \multirow{2}{*}{ Tests } & Mean & $\begin{array}{c}\text { Means (n=53) } \\
\text { Std. Devation }\end{array}$ & Mean & $\begin{array}{c}\text { Females (n=68) } \\
\text { Std. Devation }\end{array}$ & \multirow{2}{*}{ T } \\
\hline Oral fluency & 3.21 & 1.02 & 2.64 & 1.29 & $2.65^{* *}$ \\
Anxiety of speaking & 15.75 & 4.88 & 15.84 & 4.42 & 0.098 \\
\hline
\end{tabular}

** Significant at the 0.01 level (2-tailed). 
Close inspection of Table 2 reveals that there are statistically significant differences between male and female pupils in oral fluency skills in favor of male pupils. According to this result, it becomes clear that male pupils are more fluent than female pupils in speaking English Language. On the contrary, there are no statistically significant differences between male and female pupils in their speaking anxiety.

\subsection{The Second Hypothesis}

There is a relation between speaking anxiety and oral fluency skills of primary school students with learning difficulties.

Table 3.

\begin{tabular}{ccccccc}
\hline \multirow{2}{*}{ Correlations } & \multicolumn{2}{c}{ Means (n=53) } & \multicolumn{2}{c}{ Females (n=68) } & \multicolumn{2}{c}{ Total(n=120) } \\
& $\begin{array}{c}\text { Oral } \\
\text { fluency }\end{array}$ & $\begin{array}{c}\text { Anxiety of } \\
\text { speaking }\end{array}$ & $\begin{array}{c}\text { Oral } \\
\text { fluency }\end{array}$ & $\begin{array}{c}\text { Anxiety of } \\
\text { speaking }\end{array}$ & $\begin{array}{c}\text { Oral } \\
\text { fluency }\end{array}$ & $\begin{array}{c}\text { Anxiety of } \\
\text { speaking }\end{array}$ \\
\hline Oral fluency & 1 &,$- 339^{*}$ & 1 &,- 227 & 1 &,$- 262^{* *}$ \\
Anxiety of speaking &,$- 339^{*}$ & 1 &,- 227 & 1 &,$- 262^{* *}$ & 1 \\
\hline
\end{tabular}

** Significant at the 0.01 level (2-tailed).

Table 3 shows Pearson correlation coefficients between Oral fluency and Anxiety of speaking of the Means $(\mathrm{N}=53)$ reveals that there is a negative relationship between Oral fluency and Anxiety of speaking.

\subsection{The Third Hypothesis}

Oral fluency has a predictive ability to predict pupils' speaking anxiety.

The variable predictive ability of the Oral fluency differs as the performance competency on Anxiety of speaking differs.

Table 4.

\begin{tabular}{lllllll}
\hline \multirow{2}{*}{ Dependent variables } & \multirow{2}{*}{ Independent variables } & \multicolumn{2}{c}{ Total sample $=(\mathbf{1 2 0})$} & & T value \\
\hline Anxiety of speaking & & $\mathbf{R}$ & $\mathbf{R ~ 2}$ & Beta & f & $2.967^{* *}$ \\
Constant & Oral fluency & 0.262 & 0.069 & $0.262-$ & $8.805^{* *}$ & $17.62^{* *}$ \\
\hline
\end{tabular}

** Significant at the 0.01 level (2-tailed).

It is so clear from investigating Table 4 that the static variable is statistically significant. It refers that oral fluency skills has a statistically effective impact on the sample of the study. This eventually refers that the oral fluency has an ability to predict the pupils' English Language Speaking anxiety.

\section{Discussion}

Findings of the study revealed that there are statistically significant differences between male and female pupils in oral fluency skills in favor of male pupils. It becomes clear that male pupils are more fluent than female pupils in speaking English Language. This result seems to be logical because girls-in Arab environment whether they are normal or suffering learning difficulties-feel shy to speak especially in front of people. On the contrary, there are no statistically significant differences between male and female pupils in their speaking anxiety.

Results also revealed that there is a negative relation between speaking anxiety and oral fluency skills of primary school students with learning difficulties. This result coincides with the results obtained by Aida (1994) which revealed that anxiety has been found to negatively influence speaking performance. In addition, results of Lindy (2006) indicated that speaking anxiety adversely affect oral performance of English language.

Concerning the ability of Oral fluency skills to predict pupils' speaking anxiety, it is so clear that the static variable is statistically significant. It refers that the oral fluency has an ability to predict the pupils' English Language Speaking anxiety.

\section{Conclusions}

Using English language for better communication with others depends mainly on the use of speaking skills. 
People usually deliver information to others and receive information from them thus they have to respond to these stimuli. Therefore, speaking skills are so crucial for all of us whether inside the classroom or outside. Speaking skills are not influenced by the students' academic skills but it is drastically influenced by the level of anxiety they feel.

Large amount of students feel anxious when they have to speak in English in the classroom. Therefore, teachers have to alleviate their speaking anxiety in order to help them to speak accurately and fluently. Using effective strategies may help them to cease speaking anxiety, raise their motivation and increase their self-confidence.

\section{References}

Aida, Y. (1994). Examination of Horwitz, and Cope's construct of foreign language anxiety: The case of students of Japanese. Modern Language Journal, 78(2), 155-168. http://dx.doi.org/10.1111/j.1540-4781.1994. tb02026.x

Berko, R. M., Wolvin, A. D., \& Wolvin, D. R. (2004). Communication: A social and career Focus (9th ed.). Boston: Hougton Mifflin Company.

Celce-Murcia, M., Brinton, D., \& Goodwin, J. (1996). Teaching pronunciation: Reference for teacher of English to speakers of other languages. Cambridge, UK: Cambridge University Press.

Dorgham, R. A. S. (2011). The effectiveness of a proposed program in developing the speaking skills of English language among preparatory stage pupils in the light of multiple intelligences theory. Unpublished $\mathrm{PhD}$ thesis. Institute of Educational Studies. Cairo University.

El Naggar, Z. (2000). Learners' individual differences. In Z. El Naggar, R. Fadel, M. McClosky, \& B. Thoronton (Eds.), SPEER (Spotlight on Primary English Education Resources): A resource text for Egyptian primary English educators, supervisors and teachers. Academy for educational Development.

El-Basel, R. M. (2008). The Effectiveness of Multimedia Program Using Animation to Develop the Speaking Skill in English for the Pupils of the Primary Stage. MA Thesis, Cairo University, Institute of Educational Studies.

Elbeheri, G., Abu Al-diyar, Everatt, J., \& Mahfoudhi, A. (2010). Standardized Test of Reading and spelling. Kuwait: Centre of children Evaluation and teaching.

Fang-Peng, G., \& Dong, Y. (2010). A study on college students' anxiety to spoken English. Canadian social sciences, 6(2), 95-101.

Harmer, J. (2001). The Practice of English Language Teaching. Longman: Longman Press.

Horwitz, E. K., Horwitz, B., \& Cope, J. (1986). Foreign Language Classroom anxiety. The modern Language Journal, 70, 125-132. http://dx.doi.org/10.1111/j.1540-4781.1986.tb05256.x

Idri, N. (2012). Foreign Language Anxiety among Algerian EFL students: The case of first year students of English at the University Abderahmane Mira-Bejaia: LMD (license/Master/Doctorate) System Group. Universal Journal of Education and General Studies, 1(3), 55-64.

Kessler, G. (2010). Fluency and anxiety in self-access speaking tasks: The influence of environment. Computer Assisted Language Learning, 23(4), 361-375. http://dx.doi.org/10.1080/09588221.2010.512551

Kessler, R. C., McGonagle, K. A., Zhao, S., Nelson, C. B., Hughes, M., Eshleman, S., ..., Kendler, K. S. (1994). Lifetime and 12-month prevalence of DSM-III-R Psychiatric Disorders in the United States. Archives of General Psychiatry, 51, 8-19. http://dx.doi.org/10.1001/archpsyc.1994.03950010008002

Krashen, S. D. (1985). The input hypothesis: Issues and implications. New York: Longman.

Lindy, W. (2006). Anxiety and Speaking English as a Second Language. RELC Journal, 37(3), 308. http://dx.doi.org/10.1177/0033688206071315

Liu, M. (2007). Anxiety in oral English classrooms: A case study in China. Indonesian Journal of English Language Teaching, 3(1), 119-137.

Melouah, A. (2013). Foreign Language Anxiety in EFL speaking classrooms: A case study of first-year LMD students of English at Saad Dahlab University of Blida, Algeria. Arab world English Journal, 4(1), 64-76.

Mohamed, A. R., \& Wahid, N. D. (2009). Anxiety and Speaking English as a second language among male and female business students in university Industry Selangor. Segi Review, 2(2), 65-84.

Oxford, R. L. (1999). Anxiety and the language learner: New Insights. In J. Arnold (Ed.), Affect in Language 
Learning. Cambridge: Cambridge University Press.

Pertaub, D., Slater, M., \& Barke, C. (2010). An Experiment on Public Speaking Anxiety in Response to Three Different Types of Virtual Audience. University College London.

Subasi, G. (2010). What are the main sources of Turkish EFL students' anxiety in oral practice? Turkish online Journal of Qualitative Inquiry, 1(2), 29-49.

Trang, T., Baldauf, R., \& Moni, K. (2013). Foreign Language Anxiety: Understanding Its Status and Insiders' Awareness and Attitudes. TESOL Quarterly, 47(2), 216-243. http://dx.doi.org/10.1002/tesq.85

Tsiplakides, I., \& Keramida, A. (2009). Helping students overcome foreign Language Speaking Anxiety in the English Classroom: Theoretical Issues and practical Recommendations. International Education studies, 2(4), 39-44. http://dx.doi.org/10.5539/ies.v2n4p39

Yahya, M. (2013). Measuring speaking anxiety among speech communication course students at the Arab American University of Jenin (AAUJ). European Social Sciences Research Journal, 1(3), 229-248.

\section{Copyrights}

Copyright for this article is retained by the author(s), with first publication rights granted to the journal.

This is an open-access article distributed under the terms and conditions of the Creative Commons Attribution license (http://creativecommons.org/licenses/by/3.0/). 